\title{
Lack of Association between FCRL3 and FcyRII Polymorphisms in Japanese Type 1 Autoimmune Hepatitis
}

Takeji Umemura ${ }^{a}$, Masao Ota ${ }^{b}$, Kaname Yoshizawa $^{a}$, Yoshihiko Katsuyama ${ }^{c}$, Tetsuya Ichijo ${ }^{\text {a }}$, Eiji Tanaka ${ }^{a}$, Shigeyuki Kawa ${ }^{d}$, Kendo Kiyosawa ${ }^{a}$

a Department of Internal Medicine, Division of Gastroenterology and Hepatology,

Shinshu University School of Medicine, Matsumoto 390-8621, Japan

${ }^{b}$ Department of Legal Medicine, Shinshu University School of Medicine, Matsumoto 390-8621, Japan

${ }^{c}$ Department of Pharmacy, Shinshu University School of Medicine, Matsumoto 390-8621, Japan

${ }^{d}$ Center for Health, Safety and Environmental Management, Shinshu University,

Matsumoto 390-8621, Japan

Corresponding author: Takeji Umemura, MD, PhD.

Department of Internal Medicine, Division of Gastroenterology and Hepatology,

Shinshu University School of Medicine, 3-1-1 Asahi, Matsumoto 390-8621, Japan.

Tel:+81-263-37-2634, Fax:+81-263-32-9412, E-mail: t-ume@hsp.md.shinshu-u.ac.jp 


\section{Abstract}

Autoimmune hepatitis $(\mathrm{AlH})$ is an organ-specific autoimmune disease

characterized by chronic inflammation of the liver. Although the HLA-DRB ${ }^{*} 0405$ allele is associated with type $1 \mathrm{AlH}$ in Japanese, the exact genetic etiology of AlH remains

undefined. Recently, polymorphisms of Fcy receptors (FcyR) and Fc receptor-like gene 3 (FCRL3) were linked to a variety of autoimmune diseases, and may be at least partially responsible for susceptibility to AlH. In this study, we genotyped FcyRIIA, FcyRIIB, and four FCRL3 polymorphisms in 87 Japanese patients with type 1 AlH and 97 ethnically matched controls using the TaqMan assay. Although we were able to detect significantly lower serum IgG concentrations in AIH patients specifically with the FCRL3-110A/A genotype, we observed no difference in the distribution of the genotypes between patients and controls, implying that susceptibility to type $1 \mathrm{AlH}$ in Japanese patients is not influenced by FcyRIIA, FcyRIIB, or FCRL3 polymorphisms.

Key words: Autoimmune hepatitis; Genetic susceptibility; FCRL3; FcyRIIA; FcyRIIB; HLA 
Autoimmune hepatitis $(\mathrm{AlH})$ is an organ-specific autoimmune disease characterized by chronic inflammation of the liver, elevated transaminase levels, hypergammaglobulinemia, serum autoantibodies, histologic evidence of interface hepatitis, and a favorable response to immunosuppressive treatment [1-3]. Type $1 \mathrm{AlH}$ is ditinguished by the presence of circulating antinuclear antibodies and/or smooth muscle antibodies, and is the major form of AlH in Japanese and Caucasoid adults. Although this disease is believed to result from a combination of genetic and environmental factors, its exact etiology remains unidentified. In previous studies, human leukocyte antigens (HLA) DRB ${ }^{*} 0301$ and/or DRB $1{ }^{*} 0401$ alleles in Caucasians [4-6] and the DRB1 ${ }^{*} 0405$ allele in Japanese $[7,8]$ were identified as independent determinants of AlH susceptibility. However, HLA alone does not explain the entire genetic predisposition to $\mathrm{AlH}$, mainly since at least $30-40 \%$ of patients with the disease do not carry the most common susceptibility alleles. In this regard, non-HLA genes may also contribute to the disease process [9].

Recent research has identified a new family of genes, the Fc receptor-like genes, FCRLs [10] (also known as FcRHs [11,12], IRTAs [13,14] or SPAPs [15]), whose clusters locate near 1q21. FCRLs show high structural homology with classical Fcy receptor genes, and these receptors may be at least partially responsible for susceptibility to autoimmune diseases, though their ligands and functions are not yet known. Kochi et al. [16] reported that a single nucleotide polymorphism (SNP) in the promoter region of FCRL3 is associated with susceptibility to rheumatoid arthritis, autoimmune thyroid disease, and systemic lupus erythematosus in the Japanese population. This polymorphism alters the binding affinity of nuclear factor-KB and regulates FCRL3 expression. Another study from Japan supports this genetic association of the FCRL3 promoter polymorphism with rheumatoid arthritis [17]. Additionally, we previously found that the FCRL3-110 allele is associated with susceptibility to Japanese autoimmune pancreatitis and is positively correlated with serum IgG4 concentrations, which is associated with disease activity [18].

There are three Fcy receptor type II (FcyRII) genes (FcyRlla, FcyRIlb and FcyRIIc) that have been physically mapped around a 200kb span at 1q23 [19]. FcyR receptors confer potent cellular effector functions to the specificity of IgG. FcyR-induced leukocyte functions, including antibody-dependent cellular cytoxicity, phagocytosis, cytokine production, and regulation of antibody production, are essential for host defense and immune regulation. FcyRlla is the most widely distributed subclass, and is expressed on virtually all myeloid cells, including platelets. The expression of FcyRllb is restricted to phagocytes and B cells. Although FcyRlla and FcyRllb polymorphisms in 
particular have been reported to be associated with genetic susceptibility to rheumatoid arthritis and systemic lupus erythematosus [19-22], these genes have not been examined with respect to AlH susceptibility. As such we hypothesized that FCRL3, FcyRIla, and FcyRllb polymorphisms might be associated with AlH in the Japanese population. To test this hypothesis, we typed four FCRL3 SNPs, FcyRlla and FcyRIlb SNPs in patients with $\mathrm{AlH}$ and controls.

\section{Materials and methods}

\section{Subjects}

A total of 87 patients with type $1 \mathrm{AlH}$ ( 73 women, median age 56 years old, range 23-85 years) and 97 healthy subjects participated in this study. They were all residents of Nagano Prefecture, Japan, and their racial backgrounds were all Japanese. All patients had been diagnosed according to the scoring system from the International Autoimmune Hepatitis Group [23] and were classified as having type $1 \mathrm{AlH}$ based on antibody profiles. The HLA DRB1*0405 allele was frequently found in $56(64 \%)$ of the patients with type $1 \mathrm{AlH}$, as previously published [8]. All patients were negative for the hepatitis B surface antigen, antibody to hepatitis B core antigen, and antibody to hepatitis $\mathrm{C}$ or HCV RNA in serum. Study protocols were reviewed and approved by the appropriate institutional review boards, and written informed consent was obtained from all subjects.

\section{DNA Extraction and Detection of FCRL3, FcyRlla, and FcyRIlb Polymorphisms}

Genomic DNA from patients and healthy individuals were isolated by phenolic extraction of sodium dodecyl sulfate-lysed and proteinase K-treated cells, as described previously [24].

A total of six SNPs (FcyRIla H/R131, FcyRllb I/T232, and FCRL3-169, -110, +358, and +1381) were genotyped using the SNP Genotyping Kit (Applied Biosystems, Tokyo, Japan). Polymerase chain reaction was performed with a TaqMan Assay for Real-Time PCR (7500 Real Time PCR System; Applied Biosystems), following the manufacturer's instructions.

\section{HLA Typing}

HLA class I and II alleles were determined using the Micro SSPTM DNA Typing Kit (One Lamda, Canoga Park, CA). DNA typing of DRB1 and DQB1 alleles was performed by polymerase chain reaction-restriction fragment length polymorphism analysis, as previously described [24].

\section{Statistical Analysis}

The significance of allele distribution in AlH patients and normal controls was 
tested by the $\chi^{2}$ test for two-by-two or two-by-three comparisons, and a $P$ value of $\leq 0.05$ was considered significant. We also compared the genotypes of each polymorphism with clinical characteristics of the patients using the $\chi^{2}$ test for two-by-two or two-by-three comparisons, as well as the Student's $t$-test. Hardy-Weinberg equilibrium and linkage disequilibrium were analyzed using Gene Pop on the Web (http://wbiomed.curtin.edu.au/genepop/).

\section{Results}

Polymorphisms in the FCRL3, FcyRlla, and FcyRllb genes were analyzed in our $87 \mathrm{AlH}$ patients and 97 healthy subjects and summarized in tables 1 and 2 . The observed genotype frequencies for patients and controls were all in Hardy-Weinberg equilibrium. The allelic frequencies in controls have been reported previously [18], and were similar to those reported in other Japanese populations prior to this study $[16,20]$. Analysis of allelic frequencies revealed no significant difference between AlH patients and control subjects for FCRL3, FcyRlla, or FcyRIlb polymorphisms.

As observed in a study by Kochi et al.[16], FCRL3 polymorphisms are all linked (data not shown), so we therefore inferred three common haplotypes (Table 3). The haplotype frequency in controls was similar to previously reported Japanese control subjects [16], and there was no significant difference found between AlH patients and controls.

Since we previously reported that the HLA DRB $1^{*} 0405$ allele is associated with type $1 \mathrm{AlH}$ in Japan [7,8], we further investigated the genetic association between this allele and the FCRL3, FcyRIla, and FcyRllb polymorphisms (Table 4). Analysis of allelic frequencies revealed no significant difference between patients with and without the HLA DRB $1{ }^{*} 0405$ allele and these polymorphisms in $\chi^{2}$ tests for two-by-three comparisons.

We also found no significant difference between FCRL3, FcyRlla, and FcyRllb polymorphisms and clinical characteristics in relation to age, sex, or serum levels of ALT. As shown in figure 1, mean serum IgG concentrations were significantly lower in patients with genotype FCRL3-110 A/A than in those with $-110 \mathrm{G} / \mathrm{G}(2144.0 \pm 391.1 \mathrm{mg} / \mathrm{dL}$ vs. $3307.4 \pm 180.3 \mathrm{mg} / \mathrm{dL} ; P=0.042$ by Student's $t$-test).

\section{Discussion}

In our previous studies, the HLA DRB $1{ }^{*} 0405$ allele was determined to correlate with an increased prevalence of AlH in the Japanese population [7,8]. However, because none of the identified genetic markers were sufficient to fully explain disease etiology, a number of genes outside the major histocompatibility complex region were suspected to play a role in AlH susceptibility. For instance, polymorphisms of the CTLA-4, TNF- $\alpha$, VDR, and Fas genes have all been identified as correlating with an increased prevalence of 
$\mathrm{AlH}$, though these findings have been disputed [8,25-30]. Still, FCRL3 and FcyR genes emerged as attractive candidates for this study, since they have previously been implicated in other autoimmune diseases.

This study produced three main observations that warrant further comment. First, none of the FCRL3, FcyRIla, or FcyRIlb alleles were found to be associated with susceptibility or resistance to type $1 \mathrm{AlH}$ in our test group. Second, no genetic association between the HLA DRB1*0405 allele and FCRL3, FcyRlla, or FcyRllb alleles was found in patients with AlH. Finally, mean serum IgG concentrations were significantly lower in patients with genotype FCRL3-110 A/A than in those with -110G/G, which suggests that the FCRL3-110 allele might influence serum IgG concentrations in type $1 \mathrm{AlH}$.

FcyR receptors serve as a link between the humoral and cellular branches of the immune system [19]. FcyRlla displays a $G$ to $A$ point mutation in the region specifying its ligand binding domain, causing an arginine to histidine amino acid substitution at position 131. A single $T$ to $C$ nucleotide change specifying an isoleucine or threonine at position 232 was recently described in the transmembrane region of FcyRIlb. FcyR polymorphisms influence the efficacy of cellular responses, and have been associated with inflammatory diseases and disease severity. A meta-analysis has confirmed the association between FcyRIla-R131 and SLE [31].

The FCRL3 gene was recently discovered to be transcribed by nuclear factor-KB. Of particular note, the susceptibility $C$ allele of the FCRL3-169 SNP has been shown to alter FCRL3 expression through nuclear factor-KB promoter binding, leading to higher FCRL3 expression on B cells [16]. FCRL3 molecules contain both immunotyrosine activation and inhibitory motifs, enabling them to both activate and inhibit signaling pathways, and are believed to be involved in regulating cellular signaling thresholds. FCRL3 polymorphisms have been shown to be associated with various autoimmune diseases such as rheumatoid arthritis, autoimmune thyroid disease and systemic lupus erythematosus in Japanese populations [16,17]. Furthermore, we previously reported that the FCRL3-110A/A allele is associated with autoimmune pancreatitis [18]. However, there were no correlations between FCRL3, FcyRIla, and FcyRllb polymorphisms and type $1 \mathrm{AlH}$ in this study. These results suggest that $\mathrm{AlH}$ has a different immunogenic background than the above diseases with regards to these genes.

As reported by Hiraide et al.[25], Fas gene polymorphisms and haplotypes are associated with AlH in Japanese, and are predominantly present in DR4-positive AlH patients. Due to the fact that the HLA DRB $1^{*} 0405$ allele is associated with type $1 \mathrm{AlH}$ in Japanese, we also sought to determine the correlation between HLA and polymorphisms 
of FcyR receptors and FCRL3. However, no association between the HLA DRB1*0405 allele and these polymorphisms was found in this study. We previously showed that two markers of the HLA DRB1 ${ }^{*} 0405-D Q B 1{ }^{*} 0401$ haplotype and FCRL3-110 alleles were susceptible to autoimmune pancreatitis, though no association between this haplotype and FCRL3-110 alleles was found as well [18]. Since FcyR and FCRL3 are located on different chromosomes than HLA-DR, there is no linkage disequilibrium between these genes.

A previous study reported that the FCRL3-110 allele influences serum IgG4 concentrations in autoimmune pancreatitis, which is associated with disease activity [18]. In our study, serum IgG levels were significantly lower in AlH patients homozygous for the FCRL3-110A/A polymorphism than in those that were homozygous for the FCRL3-110G/G genotype. However, as there were only 4 patients with the -110A/A genotype in our cohort, it might be better to conclude this association following more studies with larger -110A/A test groups. Serum IgG4 levels were not detected in the present study since serum was not available in storage and there had been no prior association between disease activity and serum IgG4 concentration in AlH. Nonetheless, our results suggest that the FCRL3-110 allele may play a pivotal role in the secretion of IgG or IgG4 in patients with AlH and autoimmune pancreatitis, respectively. At present, we can only describe the observation of these correlations, but cannot yet provide a sound scientific basis for their occurrence. Further study is needed to clarify this interesting association.

In conclusion, we found that FcyRlla, FcyRllb, and FCRL3 polymorphisms are not associated with susceptibility to type $1 \mathrm{AlH}$ in Japan. However, the FCRL3-110 polymorphism may be implicated in the secretion of IgG in AlH patients. Genetic variations associated with $\mathrm{AlH}$ susceptibility remain for further investigation. A genome-wide genetic association study of AlH has been conducted in our group.

\section{Acknowledgments}

This study was in part supported by a research grant from the Japanese Ministry of Health, Labour and Welfare. The authors would like to thank Yuki Akahane, Asami Yamazaki, and Toyo Amaki for their technical assistance, and Trevor Ralph for his editorial assistance.

\section{References}


[1] E.L. Krawitt, Autoimmune hepatitis. N Engl J Med 354 (2006) 54-66.

[2] M.P. Manns, and A. Vogel, Autoimmune hepatitis, from mechanisms to therapy. Hepatology 43 (2006) S132-44.

[3] A.J. Czaja, F.B. Bianchi, H.A. Carpenter, E.L. Krawitt, A.W. Lohse, M.P. Manns, I.G. McFarlane, G. Mieli-Vergani, G. Toda, D. Vergani, J. Vierling, and M. Zeniya, Treatment challenges and investigational opportunities in autoimmune hepatitis. Hepatology 41 (2005) 207-15.

[4] D.G. Doherty, P.T. Donaldson, J.A. Underhill, J.M. Farrant, A. Duthie, G. Mieli-Vergani, I.G. McFarlane, P.J. Johnson, A.L. Eddleston, A.P. Mowat, and et al., Allelic sequence variation in the HLA class II genes and proteins in patients with autoimmune hepatitis. Hepatology 19 (1994) 609-15.

[5] M.D. Strettell, P.T. Donaldson, L.J. Thomson, P.J. Santrach, S.B. Moore, A.J. Czaja, and R. Williams, Allelic basis for HLA-encoded susceptibility to type 1 autoimmune hepatitis. Gastroenterology 112 (1997) 2028-35.

[6] A.J. Czaja, M.D. Strettell, L.J. Thomson, P.J. Santrach, S.B. Moore, P.T. Donaldson, and R. Williams, Associations between alleles of the major histocompatibility complex and type 1 autoimmune hepatitis. Hepatology 25 (1997) 317-23.

[7] T. Seki, K. Kiyosawa, H. Inoko, and M. Ota, Association of autoimmune hepatitis with HLA-Bw54 and DR4 in Japanese patients. Hepatology 12 (1990) 1300-4.

[8] K. Yoshizawa, M. Ota, Y. Katsuyama, T. Ichijo, A. Matsumoto, E. Tanaka, and K. Kiyosawa, Genetic analysis of the HLA region of Japanese patients with type 1 autoimmune hepatitis. J Hepatol 42 (2005) 578-84.

[9] P.T. Donaldson, Genetics in autoimmune hepatitis. Semin Liver Dis 22 (2002) 353-64.

[10] L.J. Maltais, R.C. Lovering, A.V. Taranin, M. Colonna, J.V. Ravetch, R. Dalla-Favera, P.D. Burrows, M.D. Cooper, and R.S. Davis, New nomenclature for Fc receptor-like molecules. Nat Immunol 7 (2006) 431-2.

[11] R.S. Davis, Y.H. Wang, H. Kubagawa, and M.D. Cooper, Identification of a family of Fc receptor homologs with preferential B cell expression. Proc Natl Acad Sci U S A 98 (2001) 9772-7.

[12] R.S. Davis, G.R. Ehrhardt, C.M. Leu, M. Hirano, and M.D. Cooper, An extended family of Fc receptor relatives. Eur J Immunol 35 (2005) 674-80.

[13] G. Hatzivassiliou, I. Miller, J. Takizawa, N. Palanisamy, P.H. Rao, S. lida, S. Tagawa, M. Taniwaki, J. Russo, A. Neri, G. Cattoretti, R. Clynes, C. Mendelsohn, R.S. Chaganti, and R. Dalla-Favera, IRTA1 and IRTA2, novel immunoglobulin 
superfamily receptors expressed in B cells and involved in chromosome 1q21 abnormalities in B cell malignancy. Immunity 14 (2001) 277-89.

[14] I. Miller, G. Hatzivassiliou, G. Cattoretti, C. Mendelsohn, and R. Dalla-Favera, IRTAs: a new family of immunoglobulinlike receptors differentially expressed in $B$ cells. Blood 99 (2002) 2662-9.

[15] M.J. Xu, R. Zhao, H. Cao, and Z.J. Zhao, SPAP2, an Ig family receptor containing both ITIMs and ITAMs. Biochem Biophys Res Commun 293 (2002) 1037-46.

[16] Y. Kochi, R. Yamada, A. Suzuki, J.B. Harley, S. Shirasawa, T. Sawada, S.C. Bae, S. Tokuhiro, X. Chang, A. Sekine, A. Takahashi, T. Tsunoda, Y. Ohnishi, K.M. Kaufman, C.P. Kang, C. Kang, S. Otsubo, W. Yumura, A. Mimori, T. Koike, Y. Nakamura, T. Sasazuki, and K. Yamamoto, A functional variant in FCRL3, encoding Fc receptor-like 3 , is associated with rheumatoid arthritis and several autoimmunities. Nat Genet 37 (2005) 478-85.

[17] K. Ikari, S. Momohara, T. Nakamura, M. Hara, H. Yamanaka, T. Tomatsu, and N. Kamatani, Supportive evidence for a genetic association of the FCRL3 promoter polymorphism with rheumatoid arthritis. Ann Rheum Dis 65 (2006) 671-673.

[18] T. Umemura, M. Ota, H. Hamano, Y. Katsuyama, K. Kiyosawa, and S. Kawa, Genetic association of Fc receptor-like 3 polymorphisms with autoimmune pancreatitis in Japanese patients. Gut (in press).

[19] N.M. van Sorge, W.L. van der Pol, and J.G. van de Winkel, FcgammaR polymorphisms: Implications for function, disease susceptibility and immunotherapy. Tissue Antigens 61 (2003) 189-202.

[20] C. Kyogoku, H.M. Dijstelbloem, N. Tsuchiya, Y. Hatta, H. Kato, A. Yamaguchi, T. Fukazawa, M.D. Jansen, H. Hashimoto, J.G. van de Winkel, C.G. Kallenberg, and $\mathrm{K}$. Tokunaga, Fcgamma receptor gene polymorphisms in Japanese patients with systemic lupus erythematosus: contribution of FCGR2B to genetic susceptibility. Arthritis Rheum 46 (2002) 1242-54.

[21] C. Kyogoku, N. Tsuchiya, H. Wu, B.P. Tsao, and K. Tokunaga, Association of Fcgamma receptor IIA, but not IIB and IIIA, polymorphisms with systemic lupus erythematosus: A family-based association study in Caucasians. Arthritis Rheum 50 (2004) 671-3.

[22] H. Kono, C. Kyogoku, T. Suzuki, N. Tsuchiya, H. Honda, K. Yamamoto, K. Tokunaga, and Z. Honda, FcgammaRIIB lle232Thr transmembrane polymorphism associated with human systemic lupus erythematosus decreases affinity to lipid rafts and attenuates inhibitory effects on B cell receptor signaling. Hum Mol Genet 14 (2005) 2881-92. 
[23] F. Alvarez, P.A. Berg, F.B. Bianchi, L. Bianchi, A.K. Burroughs, E.L. Cancado, R.W. Chapman, W.G. Cooksley, A.J. Czaja, V.J. Desmet, P.T. Donaldson, A.L. Eddleston, L. Fainboim, J. Heathcote, J.C. Homberg, J.H. Hoofnagle, S. Kakumu, E.L. Krawitt, I.R. Mackay, R.N. MacSween, W.C. Maddrey, M.P. Manns, I.G. McFarlane, K.H. Meyer zum Buschenfelde, M. Zeniya, and et al., International Autoimmune Hepatitis Group Report: review of criteria for diagnosis of autoimmune hepatitis. J Hepatol 31 (1999) 929-38.

[24] M. Ota, Y. Katsuyama, A. Kimura, K. Tsuchiya, M. Kondo, T. Naruse, N. Mizuki, K. Itoh, T. Sasazuki, and H. Inoko, A second susceptibility gene for developing rheumatoid arthritis in the human MHC is localized within a 70-kb interval telomeric of the TNF genes in the HLA class III region. Genomics 71 (2001) 263-70.

[25] A. Hiraide, F. Imazeki, O. Yokosuka, T. Kanda, H. Kojima, K. Fukai, Y. Suzuki, A. $\mathrm{Hata}$, and $\mathrm{H}$. Saisho, Fas polymorphisms influence susceptibility to autoimmune hepatitis. Am J Gastroenterol 100 (2005) 1322-9.

[26] K. Agarwal, A.J. Czaja, D.E. Jones, and P.T. Donaldson, Cytotoxic T lymphocyte antigen-4 (CTLA-4) gene polymorphisms and susceptibility to type 1 autoimmune hepatitis. Hepatology 31 (2000) 49-53.

[27] P.L. Bittencourt, S.A. Palacios, E.L. Cancado, G. Porta, F.J. Carrilho, A.A. Laudanna, J. Kalil, and A.C. Goldberg, Cytotoxic T lymphocyte antigen-4 gene polymorphisms do not confer susceptibility to autoimmune hepatitis types 1 and 2 in Brazil. Am J Gastroenterol 98 (2003) 1616-20.

[28] A. Vogel, C.P. Strassburg, and M.P. Manns, Genetic association of vitamin D receptor polymorphisms with primary biliary cirrhosis and autoimmune hepatitis. Hepatology 35 (2002) 126-31.

[29] S. Cookson, P.K. Constantini, M. Clare, J.A. Underhill, W. Bernal, A.J. Czaja, and P.T. Donaldson, Frequency and nature of cytokine gene polymorphisms in type 1 autoimmune hepatitis. Hepatology 30 (1999) 851-6.

[30] P.L. Bittencourt, S.A. Palacios, E.L. Cancado, G. Porta, S. Drigo, F.J. Carrilho, A.A. Laudanna, J. Kalil, and A.C. Goldberg, Autoimmune hepatitis in Brazilian patients is not linked to tumor necrosis factor alpha polymorphisms at position -308. $\mathrm{J}$ Hepatol 35 (2001) 24-8.

[31] F.B. Karassa, T.A. Trikalinos, and J.P. Ioannidis, Role of the Fcgamma receptor Ila polymorphism in susceptibility to systemic lupus erythematosus and lupus nephritis: a meta-analysis. Arthritis Rheum 46 (2002) 1563-71. 
Table 1. FCRL3 Polymorphisms in Patients with Type 1 AlH and Healthy Controls $\mathrm{AlH} \quad$ Controls

\begin{tabular}{ccccc} 
Genotype & $(\mathrm{n}=87)$ & $(\mathrm{n}=97)$ & $\chi^{2}$ & $P$ \\
\hline-169 & & & & \\
$\mathrm{C} / \mathrm{C}$ & $13(14.9)$ & $11(11.3)$ & 0.26 & 0.61 \\
$\mathrm{C} / \mathrm{T}$ & $45(51.7)$ & $51(52.6)$ & 0.00 & 0.97 \\
$\mathrm{~T} / \mathrm{T}$ & $29(33.3)$ & $35(36.1)$ & 0.05 & 0.81 \\
-110 & & & & \\
$\mathrm{~A} / \mathrm{A}$ & $4(4.6)$ & $2(2.1)$ & 0.30 & 0.58 \\
$\mathrm{~A} / \mathrm{G}$ & $34(39.1)$ & $35(36.1)$ & 0.07 & 0.79 \\
$\mathrm{G} / \mathrm{G}$ & $49(56.3)$ & $60(61.9)$ & 0.38 & 0.54 \\
+358 & & & & \\
$\mathrm{C} / \mathrm{C}$ & $13(14.9)$ & $11(11.3)$ & 0.26 & 0.61 \\
$\mathrm{C} / \mathrm{G}$ & $45(51.7)$ & $51(52.6)$ & 0.00 & 0.97 \\
G/G & $29(33.3)$ & $35(36.1)$ & 0.05 & 0.81 \\
+1381 & & & & \\
A/A & $29(33.3)$ & $35(36.1)$ & 0.05 & 0.81 \\
$\mathrm{~A} / \mathrm{G}$ & $13(14.9)$ & $11(11.3)$ & 0.26 & 0.61 \\
$\mathrm{G} / \mathrm{G}$ & $45(51.7)$ & $51(52.6)$ & 0.00 & 0.97 \\
\hline
\end{tabular}


Table 2. FcyRlla and FcyRIlb Polymorphisms in Patients with Type $1 \mathrm{AlH}$ and Healthy Controls

\begin{tabular}{lcccc}
\hline & AlH & Controls & & \\
Genotype & $(\mathrm{n}=87)$ & $(\mathrm{n}=97)$ & $\chi^{2}$ & $P$ \\
\hline FcyRlla $/ 131$ & & & \\
$\mathrm{R} / \mathrm{R}$ & $4(4.6)$ & $5(5.2)$ & 0.03 & 0.87 \\
$\mathrm{R} / \mathrm{H}$ & $30(34.5)$ & $32(33.0)$ & 0.00 & 0.95 \\
$\mathrm{H} / \mathrm{H}$ & $53(60.9)$ & $60(61.9)$ & 0.00 & 0.98 \\
$\mathrm{Fc \gamma R} / \mathrm{lb} / 232$ & & & & \\
$\mathrm{I} / \mathrm{I}$ & $3(3.4)$ & $4(4.1)$ & 0.02 & 0.88 \\
$\mathrm{I} / \mathrm{T}$ & $36(41.4)$ & $28(28.9)$ & 2.64 & 0.10 \\
$\mathrm{~T} / \mathrm{T}$ & $48(55.2)$ & $65(67.0)$ & 2.24 & 0.14 \\
\hline
\end{tabular}


Table 3. Association of FCRL3 Haplotypes in Type 1 AlH Patients and Healthy Controls

\begin{tabular}{|c|c|c|c|c|c|c|c|c|}
\hline \multirow[b]{3}{*}{ Haplotype } & & & & & \multicolumn{2}{|c|}{ Frequency } & \multirow{3}{*}{$\chi^{2}$} & \multirow{3}{*}{$P$} \\
\hline & & & & & Autoimmune & Healthy & & \\
\hline & & & & & hepatitis & subjects & & \\
\hline & -169 & -110 & +358 & +1381 & $(n=174)$ & $(n=194)$ & & \\
\hline 1 & $\mathrm{~T}$ & G & G & G & 0.59 & 0.62 & 0.27 & 0.61 \\
\hline 2 & $\mathrm{C}$ & $A$ & C & $A$ & 0.24 & 0.20 & 0.65 & 0.42 \\
\hline 3 & C & $G$ & C & $A$ & 0.17 & 0.18 & 0.00 & 0.94 \\
\hline
\end{tabular}

Values for $\mathrm{n}$ indicate two times the number of individuals since each person carries two haplotypes. 
Table 4. Association between HLA DRB1*0405 and FCRL3, FcyRlla, and FcyRIlb Polymorphisms in Patients with Type 1 AlH

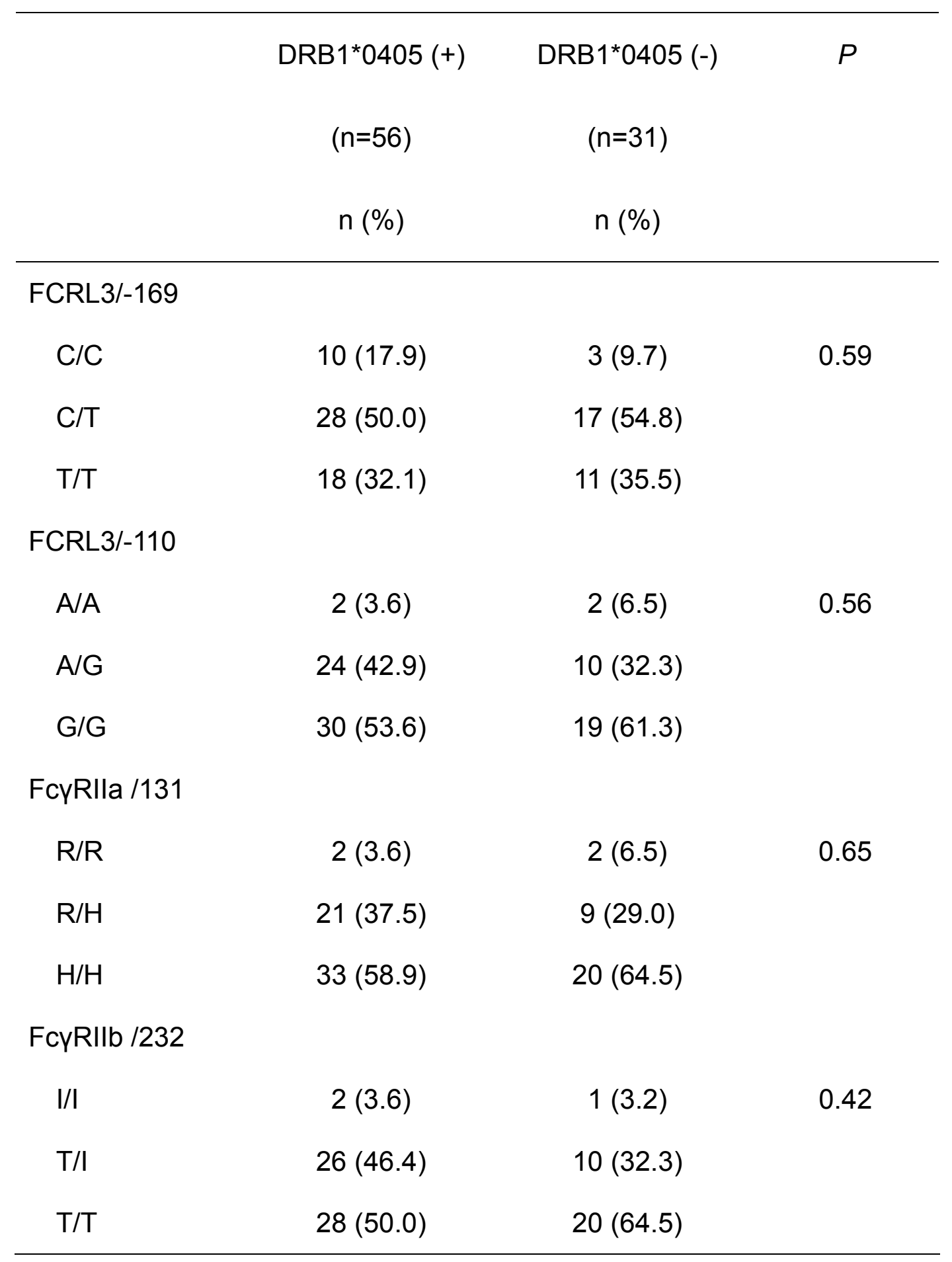


Umemura et al. 15

Figure Legend:

Figure 1. FCRL3-110 genotype and serum IgG concentrations in patients with type 1

$\underline{\mathrm{AlH}}$.

Serum IgG levels were measured in 4 patients with $-110 A / A, 27$ patients with $-110 A / G$,

and 33 patients with $-110 \mathrm{G} / \mathrm{G}$. Solid lines indicate the mean values. ${ }^{*} P=0.052$,

$\stackrel{* *}{P}=0.042$. 
Figure 1.
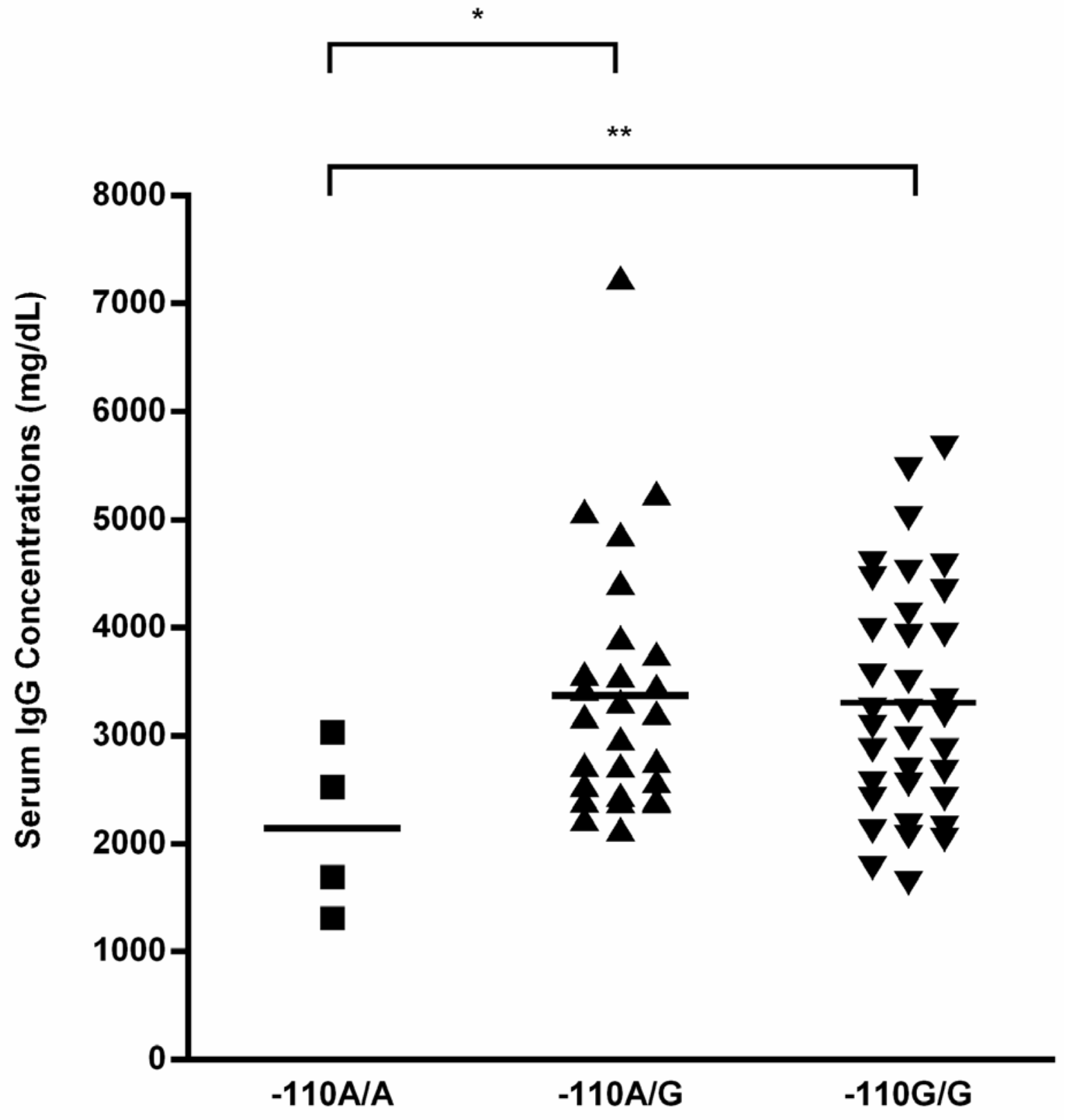